\title{
GENETIC STRUCTURE AND DIVERSITY OF Copaifera langsdorffii Desf. IN CERRADO FRAGMENTS OF THE SÃO PAULO STATE, BRAZIL ${ }^{1}$
}

Lia Maris Orth Ritter Antiqueira², Renata Gabriela Villegas de Castro e Souza ${ }^{3}$, Miklos Maximiliano Bajay²

e Paulo Yoshio Kageyama ${ }^{4}$

\begin{abstract}
The loss of large areas of Cerrado (Brazilian savanna) in Brazil can lead to reduced biodiversity and to the extinction of species. Therefore, the present study aimed to investigate the genetic fragility of populations of Copaifera langsdorffii Desf exposed to different anthropic conditions in fragments of Cerrado in the state of São Paulo. The study was carried out in two Experimental Stations operated by the Forest Institute (Assis and Itirapina), in one fully protected conservation unit (Pedregulho) and in one private property (Brotas). Analyses were conducted using leaf samples from 353 adult specimens and eight pairs of microsatellite loci. The number of alleles per locus ranged from 13 to 15 in all populations, but the mean number of effective alleles was approximately half this value (7.2 to 9-1). Observed heterozygosity was significant and lower than the expected in all populations. Consequently, all populations deviated from Hardy-Weinberg expected frequencies. Fixation indexes were significant for all populations, with the Pedregulho population having the lowest value (0.189) and Itirapina having the highest (0.283). The analysis of spatial genetic structure detected family structures at distance classes of 20 to $65 \mathrm{~m}$ in the populations studied. No clones were detected in the populations. Estimates of effective population size were low, but the area occupied by each population studied was large enough for conservation, medium and long term. Recent reductions or bottlenecks were detected in all four populations. Mean Gst' (genetic divergence) indicated that most of the variation was within populations. Cluster structure analysis based on the genotypes detected $\mathrm{K}=4$ clusters with distinct allele frequencies patterns. The genetic differentiation observed among populations is consistent with the hypothesis of genetic and geographic isolation. Therefore, it is essential to adopt conservation strategies that raise the gene flow between fragments.
\end{abstract}

Keywords: Copaíba; Gene flow; Microsatellites.

\section{ESTRUTURA E DIVERSIDADE GENÉTICA DE Copaifera langsdorffii Desf. EM FRAGMENTOS DE CERRADO NO ESTADO DE SÃO PAULO}

\begin{abstract}
RESUMO - Considerando que a perda de grandes áreas de Cerrado no Brasil pode levar à diminuição da biodiversidade e, mesmo, à extinção de espécies, questiona-se a fragilidade genética de populações de Copaifera langsdorffii Desf. expostas a diferentes condições antrópicas em fragmentos de Cerrado do Estado de São Paulo. Foram consideradas duas áreas em Estações Experimentais do Instituto Florestal (Assis e Itirapina), uma área em unidade de conservação de proteção integral (Pedregulho) e outra área de propriedade particular (Brotas). As análises foram realizadas com amostras foliares de 353 indivíduos adultos e oito pares de locos microssatélites. O número de alelos por loco variou de 13 a 15 em todas as populações, porém o número médio de alelos efetivos foi aproximadamente a metade desse valor (7,2 a 9-1). As estimativas de heterozigosidade observada foram significativas e ficaram abaixo dos valores esperados em todas as populações. Consequentemente, as populações não aderem às frequências esperadas para o Equilíbrio de Hardy-Weinberg. O índice de fixação
\end{abstract}

\footnotetext{
${ }^{1}$ Recebido em 06.07.2013 aceito para publicação em 14.04.2014.

${ }^{2}$ Universidade de São Paulo, Escola Superior de Agricultura Luiz de Queiroz, Departamento de Genética, Brasil. E-mail: <liamaris@gmail.com>e <mmbajay@gmail.com>.

${ }^{3}$ Universidade de São Paulo, Escola Superior de Agricultura Luiz de Queiroz, Brasil. E-mail: <rgvcs@yahoo.com.br>. ${ }^{4}$ Universidade de São Paulo, Escola Superior de Agricultura Luiz de Queiroz, Departamento de Ciências Florestais, Brasil. E-mail: <pkageyama@usp.br>.
} 
obteve valores significativos em todas as populações; o menor valor foi da população de Pedregulho $(0,189)$ e o maior, da população de Itirapina $(0,283)$. As análises de estrutura genética espacial indicaram a formação de estrutura familiar entre 20 e $65 \mathrm{~m}$ nas populações. Não foi detectada a presença de clones. As estimativas de tamanho efetivo populacional foram baixas, no entanto as populações possuem área mínima viável para conservação no curto e médio prazos. Foram identificadas reduções recentes ou efeito de gargalo nas quatro populações. As análises de divergência genética (Gst') indicaram que a maior parte da divergência se encontrava dentro das populações. A análise de estrutura de grupos com base nos genótipos resultou em $K=$ quatro grupos, com padrões de frequências alélicas distintas. A diferenciação genética observada entre as populações é consistente com a hipótese de seu isolamento genético e geográfico. Portanto, é imprescindível a adoção de estratégias de conservação que aumentam o fluxo gênico entre os fragmentos.

Palavras-chave: Copaíba; Fluxo gênico; Microssatélites.

\section{INTRODUCTION}

The Cerrado (Brazilian savanna) is the second largest biome in Brazil. It is a biodiversity hotspot and represents an important conservation target (MITTERMEIER et al., 2005). Although it once covered 2 million $\mathrm{km}^{2}$ of the Brazilian territory, approximately $39 \%$ of its original area has been completely destroyed (MACHADO et al., 2004), and only 3.18\% of the remaining vegetation is protected in 48 federal, state and municipal conservation units (BRASIL, 2006). In the state of São Paulo, the percentage of land covered by Cerrado vegetation has decreased from 14 to $0.74 \%$ (KRONKA et al., 2005). The remaining fragments of Cerrado are isolated by agriculture (sugarcane) and other types of forest, or surrounded by grazing land.

The fragmentation of the Cerrado biome could potentially lead to decreased biodiversity and to the extinction of species. According to Antiqueira (2013), the genetic consequences of habitat fragmentation have led the scientific community to question the genetic vulnerability of populations and to reevaluate the strategies used in the conservation of endangered species.

Copaifera langsdorffii Desf (Caesalpinioideae), known in Brazilian Portuguese as “copaíba,” is a tropical tree species with wide distribution in the Brazilian savanna and Atlantic rain forest (CARVALHO, 2003; QUEIROZ; SILVA, 2013). It is hermaphroditic, and is pollinated by Apis melifera and Trigona sp bees as well as other insects. It has a predominant outcrossing mating system with up to $8 \%$ of selfing (SEBBENN et al., 2011). Its seeds are dispersed by zoochory (OLIVEIRA et al., 2002). Copaíba trees grow slowly, and can reach up to $40 \mathrm{~m}$ in height and $100 \mathrm{~cm}$ diameter, with some individuals living for up to 400 years (CARVALHO, 2003). Copaíba trees have significant economic value as a source of wood and resin oil, which is widely used by the pharmaceutical industry to produce cosmetics and phytotherapeutic remedies.

In the state of São Paulo, C. langsdorffii specimens in both private properties and Conservation Units are limited to small fragments isolated by intensive agriculture and cattle pasture (CARVALHO et al., 2010).

The goal of the present study was to characterize the intra- and inter-population genetic variation of Copaifera langsdorffi Desf. from four Cerrado regions in the state of São Paulo and to verify if population distance and isolation can affect genetic differentiation.

\section{MATERIALS AND METHOD}

\subsection{Regions Studied}

The present study was conducted in four Cerrado regions in the state of São Paulo (Table 1). Three of these (Assis, Itirapina and Pedregulho) are operated by the Forest Institute of São Paulo, while one is in a private property (Marimbondo Farm, Brotas). The study site in Assis (22'35'14'’ S, 50²2'38' 'W, 550 m altitude) is surrounded by sugarcane plantations, grazing land and Pinus and Eucalyptus forests. Samples were collected in an area of 0.9 hectares. A similar environment surrounds the fragment located in Marimbondo Farm, in Brotas (22²2'18', S, 4801'24'”'W, 650 m altitude, 400 ha). However, the anthropic pressure is particularly high in this area, and the fragment itself is often used as grazing land. The size of the sampling area in Brotas was of approximately 1.6 hectar.

In Itirapina (22॰13’03”'S, 4750’15”'W, 750 m altitude), the 2.3 ha sampling area was also located within an Experimental Station. Like the other forest fragments, this Experimental Station is surrounded by Pinus, 
Eucalyptus and sugarcane plantations. The study site in Pedregulho (Furnas do Bom Jesus State Park,

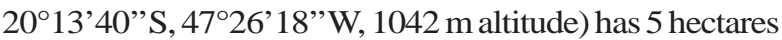
and is the only fully protected Conservation Unit. However, it is especially vulnerable to wildfires, the last of which (in 2011, unknown cause) burned 500 ha of native vegetation.

All study sites can be classified as Cerrado sensu strictu and Cerradão, according to the categories proposed by Ribeiro and Walter (1998). According to Köppen's classification (ROLIM et al., 2007), all sampled areas are located in Cfa climate zones (humid subtropical climate, no dry season), except for Pedregulho, which has an Aw climate (tropical climate with dry winters). The distances between all fragments are listed in Table 3.

\subsection{Sampling and DNA Extraction}

Leaf samples from 100 adult specimens of $C$. langsdorffii were collected in each area except for Pedregulho, where only 53 specimens were located. All subjects were geocoded. The distance range between individuals is 5-47 $\mathrm{m}$ in Assis, 5-48 $\mathrm{m}$ in Brotas, 5$58 \mathrm{~m}$ in Itpirana and 7-68 $\mathrm{m}$ in Pedregulho. Total genomic DNA extraction was carried out according to Doyle and Doyle (1990) with modifications described by Ferreira and Grattapaglia (1998). Loci were amplified using eight pairs of microsatellite loci designed for C. langsdorffii by Ciampi et al. (2000).

DNA fragments were amplified and separated using denaturing polyacrylamide gel electrophoresis in $1 \mathrm{X}$ TBE buffer for one hour and thirty minutes. A silver nitrate stain (CRESTE et al., 2001) was used to observe banding patterns. Allele size was calculated using a molecular weight standard (10bp ladder - Invitrogen $®$ ). Fragments of different sizes were considered different alleles.

\subsection{Data Analysis}

The SPAGeDI software, version 1.3 (HARDY; VEKEMANS, 2002), was used to estimate genetic diversity parameters and to analyze spatial genetic structure at the population levels. The following parameters were considered: number of alleles per locus (A), effective number of alleles per locus $\left(A_{e}\right)$, presence of exclusive alleles $\left(A_{e x}\right)$, mean observed $\left(H_{0}\right)$ and expected $\left(\mathrm{H}_{\mathrm{e}}\right)$ heterozygosity, and fixation indices $(f)$ according to Weir (1996). This software was also used to analyze spatial genetic structure within populations from the estimates of the coefficients based on recent coancestry Loiselle et al. (1995) among plants within the defined distance classes $k$ for each allele in each pair of individuals, $x$ and $y$. Kinship coefficients were estimated using the method described in Loiselle et al. (1995). Statistical significance was assessed by 10,000 permutations of genes at the Bonferroni-corrected 5\% significance level. Means for each locus were compared between populations using 95\% confidence intervals adjusted using the Jackknife method over loci.

Adherence to Hardy-Weinberg equilibrium was calculated by Fisher's exact test, using the TFPGA software (MILLER, 1997), as well as genetic distance between populations, according to Nei (1987). The presence of clones was assessed using the CERVUS 3.0 software (KALINOWSKI et al., 2007). The Bottleneck software (PIRY et al., 1999) was used to identify recent reductions in effective population size based on the excess of heterozygosity. Analyses were based on the Mutation Step (OHTA; KIMURA, 1973), Infinite Allele (KIMURA; CROW, 1964) and Two Step models (DI RIENZO et al., 1994), using the Wilcoxon test with 1,000 iterations (LUIKART; CORNUET, 1998), as recommended for analysis with fewer than 20 SSR loci (PIRY et al., 1999).

Effective population size was calculated as in Cockerham (1969), and the minimum viable area (MVA) for in situ genetic conservation was estimated as a function of the effective population sizes suggested by Lynch (1996), as recommended by Whittaker and Fernández-Palacios (2007). It is considered that MVA $=N e_{(\text {ref })} / d(\mathrm{Ne} / \mathrm{n})$ where: $\mathrm{Ne} / \mathrm{n}=$ ratio of effective population size and sample size; $d=$ density of individuals per hectare. Genetic divergence $\left(\mathrm{G}_{\mathrm{st}},\right)$ was calculated using the FSTAT software (GOUDET, 2001) by applying the Hedrick (2005) correction, which is the most suitable parameter for microsatellites. Apparent gene flow between populations was estimated according to Crow and Aoki (1984).

The cluster (K) structure was analyzed using the Structure software (PRITCHARD et al., 2000), which uses individual genotype information to identify genetic clusters, by calculating the ÄK values described by Evanno et al. (2005).

Revista Árvore, Viçosa-MG, v.38, n.4, p.667-675, 2014 
Table 1 - Description of SSR loci in the populations of Assis, Brotas, Itirapina and Pedregulho, SP. A = number of alleles; $A_{e}=$ effective number of alleles; $A_{e x}=$ number of exclusive alleles; $H_{o}=$ observed heterozygosity; $H_{e}=$ expected heterozygosity; HWE $=$ Hardy-Weinberg Equilibrium, in which $\mathrm{p}<0.5$ suggests equilibrium deviations $(*) ; f=$ fixation index; 95\% CI $\pm=95 \%$ confidence interval using 10.000 bootstrap resampling over loci; and $* *=$ significant at 0.01 level

Tabela 1 - Descrição dos locos de SSR das populações de Assis, Brotas, Itirapina e Pedregulho, SP. A = número alelos; $A_{e}=$ número efetivo de alelos; $A_{e x}=$ número de alelos exclusivos; $H_{o}=$ heterozigosidade observada; $H_{e}=$ heterozigosidade esperada; HWE = Equilíbrio de Hardy-Weinberg, em que $p<0,5$ indica desvio do equilíbrio (*); $f$ = índice de fixação; IC95\% = intervalo de confiança a 95\% de probabilidade usando 10.000 reamostragens "bootstrap" sobre locos; $e^{* *}=$ significativo a 0,01

\begin{tabular}{|c|c|c|c|c|c|c|c|c|}
\hline Assis & $\mathrm{N}$ & A & $A_{e}$ & $A_{e x}$ & $\mathrm{H}_{\mathrm{o}}$ & $\mathrm{H}_{\mathrm{e}}$ & HWE & $f$ \\
\hline$\overline{\text { CL1 }}$ & 100 & 11 & 5.5 & - & 0.660 & 0.818 & 0.074 & 0.193 \\
\hline CL2 & 98 & 14 & 10 & - & 0.745 & 0.899 & $0.001 *$ & 0.171 \\
\hline CL6 & 99 & 16 & 9.3 & - & 0.768 & 0.892 & 0.085 & 0.140 \\
\hline CL20 & 94 & 16 & 7.9 & - & 0.638 & 0.873 & 0.072 & 0.269 \\
\hline CL27 & 96 & 11 & 5 & 1 & 0.375 & 0.802 & $0.000 *$ & 0.533 \\
\hline CL32 & 97 & 18 & 11 & - & 0.845 & 0.909 & $0.004 *$ & 0.070 \\
\hline CL34 & 98 & 12 & 5.2 & - & 0.786 & 0.807 & $0.000 *$ & 0.026 \\
\hline CL39 & 83 & 15 & 8.9 & - & 0.458 & 0.888 & $0.000 *$ & 0.484 \\
\hline Mean & 95.6 & 14.1 & 7.8 & - & 0.659 & 0.861 & - & $0.236 * *$ \\
\hline $95 \%$ CI & & & & & & & & $(+-0.024)$ \\
\hline Brotas & $\mathrm{N}$ & A & $A_{e}$ & $A_{e x}$ & $\mathrm{H}_{\mathrm{o}}$ & $\mathrm{H}_{\mathrm{e}}$ & HWE & $f$ \\
\hline$\overline{\text { CL1 }}$ & 100 & 14 & 8.3 & 1 & 0.790 & 0.880 & $0.000 *$ & 0.102 \\
\hline CL2 & 99 & 14 & 9 & 4 & 0.758 & 0.890 & $0.000 *$ & 0.148 \\
\hline CL6 & 100 & 16 & 9.5 & 1 & 0.719 & 0.895 & $0.000 *$ & 0.196 \\
\hline CL20 & 96 & 18 & 7.7 & 1 & 0.677 & 0.871 & $0.000 *$ & 0.222 \\
\hline CL27 & 96 & 7 & 1.7 & 1 & 0.419 & 0.824 & $0.000 *$ & 0.419 \\
\hline CL32 & 99 & 18 & 9.2 & 2 & 0.757 & 0.891 & $0.000 *$ & 0.150 \\
\hline CL34 & 100 & 16 & 7.3 & 2 & 0.730 & 0.864 & $0.001 *$ & 0.155 \\
\hline CL39 & 98 & 23 & 15.3 & - & 0.744 & 0.935 & $0.000 *$ & 0.204 \\
\hline Mean & 98.5 & 15.7 & 8.5 & - & 0.699 & 0.881 & - & $0.198 * *$ \\
\hline $95 \% \mathrm{CI}$ & & & & & & & & $(+-0.012)$ \\
\hline Itirapina & $\mathrm{N}$ & A & $\mathrm{A}_{\mathrm{e}}$ & $A_{\text {ex }}$ & $\mathrm{H}_{\mathrm{o}}$ & $\mathrm{H}_{\mathrm{e}}$ & HWE & $f$ \\
\hline CL1 & 100 & 12 & 7.3 & 1 & 0.800 & 0.863 & $0.000 *$ & 0.073 \\
\hline CL2 & 100 & 15 & 8.9 & 1 & 0.630 & 0.886 & $0.000 *$ & 0.290 \\
\hline CL6 & 99 & 11 & 7.4 & 1 & 0.455 & 0.864 & $0.000 *$ & 0.475 \\
\hline CL20 & 99 & 18 & 8.3 & - & 0.697 & 0.878 & $0.000 *$ & 0.207 \\
\hline CL27 & 100 & 7 & 4.9 & - & 0.450 & 0.795 & $0.000 *$ & 0.435 \\
\hline CL32 & 98 & 20 & 10 & 2 & 0.531 & 0.898 & $0.000 *$ & 0.410 \\
\hline CL34 & 99 & 10 & 4.5 & 1 & 0.677 & 0.778 & $0.000 *$ & 0.131 \\
\hline CL39 & 97 & 13 & 6.4 & 5 & 0.639 & 0.844 & $0.000 *$ & 0.244 \\
\hline Mean & 99 & 15.5 & 7.2 & - & 0.610 & 0.852 & - & $0.283 * *$ \\
\hline $95 \%$ CI & & & & & & & & $(+-0.018)$ \\
\hline Pedregulho & $\mathrm{N}$ & A & $\mathrm{A}_{\mathrm{e}}$ & $\mathrm{A}_{\mathrm{ex}}$ & $\mathrm{H}_{\mathrm{o}}$ & $\mathrm{H}_{\mathrm{e}}$ & HWE & $f$ \\
\hline$\overline{C L 1}$ & 53 & 13 & 9.1 & 2 & 0.868 & 0.891 & $0.024 *$ & 0.026 \\
\hline CL2 & 53 & 12 & 8.1 & - & 0.811 & 0.877 & $0.000 *$ & 0.076 \\
\hline CL6 & 53 & 16 & 10.5 & 1 & 0.66 & 0.903 & $0.002 *$ & 0.27 \\
\hline CL20 & 52 & 20 & 14.5 & 1 & 0.808 & 0.929 & $0.000 *$ & 0.132 \\
\hline CL27 & 51 & 8 & 7 & - & 0.333 & 0.854 & $0.000 *$ & 0.612 \\
\hline CL32 & 51 & 22 & 16.1 & 5 & 0.882 & 0.937 & 0.2257 & 0.059 \\
\hline CL34 & 53 & 17 & 9.9 & 6 & 0.717 & 0.897 & $0.000 *$ & 0.203 \\
\hline CL39 & 49 & 17 & 13.1 & 2 & 0.776 & 0.922 & $0.020 *$ & 0.16 \\
\hline Mean & 51.2 & 13 & 9.1 & - & 0.732 & 0.901 & - & $0.189 * *$ \\
\hline $95 \% \mathrm{CI}$ & & & & & & & & $(+-0.026)$ \\
\hline
\end{tabular}

Revista Árvore, Viçosa-MG, v.38, n.4, p.667-675, 2014 


\section{RESULTS}

The number of alleles per locus ranged from 13 to 15 in all populations, but the mean effective number of alleles was approximately half this value (7.2 to 9.1). Exclusive alleles were also detected. The Assis population had the lowest number of exclusive alleles (1 allele, locus CL27) while Pedregulho had the highest (17 alleles, loci CL1, CL6, CL20, CL32, CL34 and CL39). Observed heterozygosity was significantly lower than the expected $\left(\mathrm{H}_{\mathrm{e}}\right)$ in all populations. Therefore, all populations deviated from Hardy-Weinberg Equilibrium (HWE), except for the CL1, CL6 and CL20 loci in the Assis population and the CL32 locus in the Pedregulho population. Fixation index values were significant for all populations, with the Pedregulho population having the lowest value (0.189) and Itirapina having the highest (0.283), as displayed in Table 1.

The analysis of spatial genetic structure (Figure 1) detected significant family structures at distance classes of $20 \mathrm{~m}$ in Assis, $25 \mathrm{~m}$ in Brotas, $65 \mathrm{~m}$ in Itirapina and $45 \mathrm{~m}$ in Pedregulho, with a tendency toward spatial structure also observed in distance classes of 80 to $90 \mathrm{~m}$. Pedigree formation was observed at these distances. In the distance classes described above, genotypes were randomly distributed.

\section{Clones were not detected in any population.}

Estimates of effective population size $\left(N_{e}\right)$ were low in all populations, and ranged from 14 to 21 individuals. The estimated minimum viable area (MVA) for in situ genetic conservation, based on the estimated effective population size, sample size and density of individuals per hectare, ranged from 3.8 and 397 ha, based on a short-term effective population size of 50 $\left(\mathrm{MVA}_{50}\right)$. Medium (MVA $\left.{ }_{500}\right)$ and long term $\left(\mathrm{MVA}_{1000}\right)$ estimates were between 38 and 3,970 ha, and between 76 and 7,936 ha, respectively (Table 2).

The analyses of reductions in population size using the Stepwise Mutation Model (SMM) did not detect bottlenecks in the examined populations. However, bottleneck effects were observed in all four populations when the Infinite Allele (IAM) and Two Phase Models (TPM) were used ( $<<0.05$, Table 2$)$.

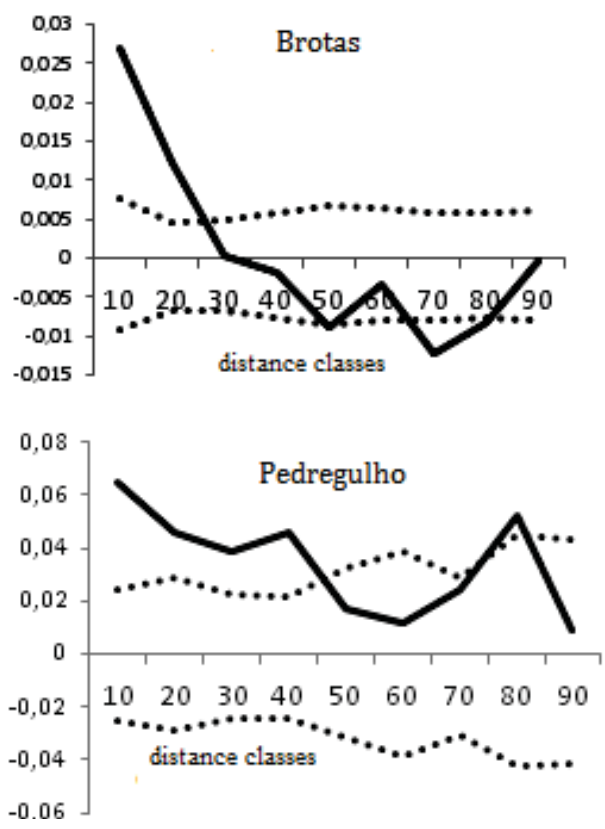

Figure 1 - Correlogram of coancestry coefficients in nine distance classes in the four populations of $C$ langsdorffii. Traced lines indicate the limits inferior and superior of the error confidence interval with 95\% probability, while solid lines indicate coancestry coefficients estimated according to Loiselle et al. (1995).

Figura 1 - Correlograma do coeficiente de coancestria em nove classes de distâncias nas quatro populações de C langsdorffii. Linhas tracejadas indicam o limite inferior e superior do intervalo de confiança do erro a 95\% de probabilidade, e a linha contínua representa a estimativa do coeficiente de coancestria, segundo Loiselle et al. (1995). 
Table 2 - Estimates of effective population size and minimum variable area (MVA) for in situ genetic conservation of C. langsdorffii Desf., and Wilcoxon test for bottlenecks in the populations of Assis, Brotas, Itirapina and Pedregulho. $\mathrm{N}=$ sample size; $N e=$ effective population size; $\mathrm{MVA}_{(1000)}=$ area required to support $N e_{(\text {ref })}=1000 ; \mathrm{MVA}_{(500)}$ $=$ area required to support $N e_{(\text {ref })}=500 ; \mathrm{MVA}_{(50)}=$ area required to support $N e_{(\text {ref })}=50 ;$ IAM $=$ Infinite Allele Model; TPM = Two Phase Model; SMM = Stepwise Mutation Model ; and * = 95\% Probability of bottlenecks $(\mathrm{p}<0.05)$.

Tabela 2 - Estimativas de tamanho efetivo, área mínima viável (AMV) para conservação genética in situ de C. langsdorffii Desf. e teste de Wilcoxon para ocorrência de gargalos genéticos nas populações de Assis, Brotas, Itirapina e Pedregulho. $N$ = tamanho amostral; $N e=$ tamanho efetivo populacional; $A M V_{(1000)}=$ área necessária para conter $N e_{(\text {ref })}=1000 ; A M V_{(500)}=$ área necessária para conter $N e_{(\text {ref })}=500 ; A M V_{(50)}=$ área necessária para conter $N e_{(r e f)}$ = 50; IAM = Modelo de Alelos Infinitos (Infinite Allele Model); TPM = Modelo de Duas Fases SMM = Modelo de Passos de Mutação; $e^{*}=$ Probabilidade a 95\% de ocorrência de Bottleneck $(p<0,05)$.

\begin{tabular}{ccccccccc}
\hline Population & $\mathrm{N}$ & $\mathrm{Ne}$ & MVA $_{(100))}$ & MVA $_{(500)}$ & MVA $_{(50)}$ & IAM & TPM & SMM \\
\hline Assis & 100 & 21 & 488 & 244 & 24 & $0.00391^{*}$ & $0.02734^{*}$ & 0.07422 \\
Brotas & 100 & 18 & 76 & 38 & 3.8 & $0.00391^{*}$ & $0.01953^{*}$ & 0.98047 \\
Itirapina & 100 & 14 & 161.3 & 80.6 & 8 & $0.00391^{*}$ & $0.01953^{*}$ & 0.07422 \\
Pedregulho & 53 & 16 & 7,936 & 3,970 & 397 & $0.00391^{*}$ & $0.00391^{*}$ & 0.38281 \\
\hline
\end{tabular}

Genetic divergence among populations (HEDRICK, 2005) was high (0.82 to 1.11), with the lowest divergence observed between Brotas and Pedregulho, and the highest between Assis and Pedregulho (Table 3).

Table 3 - Distance between study areas in kilometers and genetic divergence between populations $\left(\mathrm{G}_{\mathrm{st}}\right)$.

Tabela 3 - Distância das áreas de estudo em quilômetros e divergência genética entre populações $\left(G_{s t}\right)$.

\begin{tabular}{ccc}
\hline Regions Studied & Distance $(\mathrm{km})$ & $\mathrm{G}_{\mathrm{st}}$ \\
\hline Assis x Brotas & 275 & 1.03 \\
Assis x Itirapina & 350 & 0.93 \\
Assis x Pedregulho & 460 & 1.11 \\
Brotas x Itirapina & 24 & 0.99 \\
Brotas x Pedregulho & 280 & 0.82 \\
Itirapina x Pedregulho & 280 & 0.95 \\
\hline
\end{tabular}

Cluster analyses identified $\mathrm{K}=4$ clusters with distinct allele frequencies (Figure 2a), although some of the genotypes observed in Brotas and Itirapina were similar to each other (Figure 2b). However, in spite of the smaller genetic distance between these two populations, they are different enough to be considered distinct from each other.

\section{DISCUSSION}

The analyses of genetic diversity revealed an average of over ten alleles per locus, although there was a low effective number of alleles. The low values may also be attributable to the presence of private and rare alleles, which may indicate restricted gene flow and the beginning of population genetic differentiation. The a

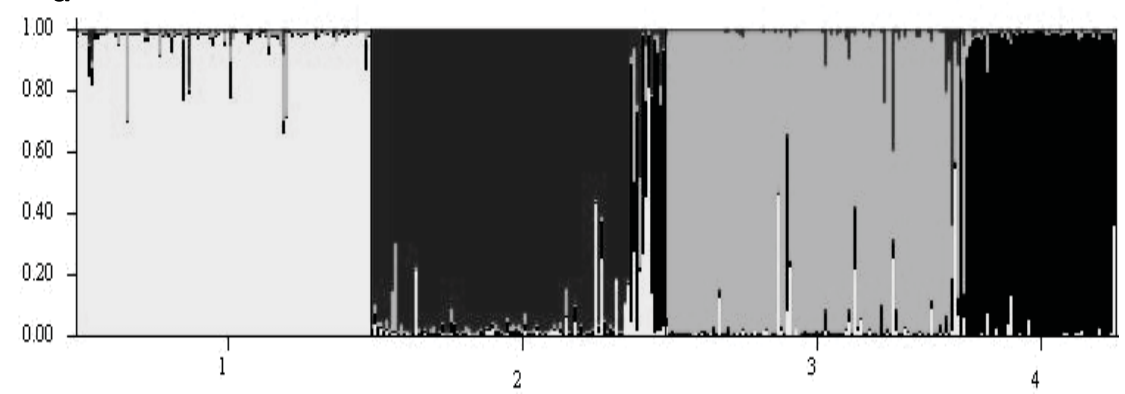

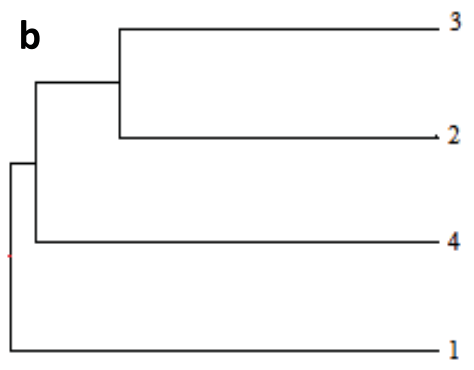

Figure 2 - a) Clusters ( $\mathrm{K}=4$ ) defined by genotypic similarities. b) Genetic distances between studied populations of $C$. langsdorffii Desf. in the state of São Paulo, in which 1 = Assis; 2 = Brotas; 3 = Itirapina; and $4=$ Pedregulho.

Figura 2 - a) Grupos ( $K=4$ ) definidos por semelhanças genotípicas. b) Distâncias genéticas entre as populações de C. Iangsdorffii Desf. estudadas no Estado de São Paulo, em que 1 = Assis; 2 = Brotas; 3 = Itirapina; e $4=$ Pedregulho.

Revista Árvore, Viçosa-MG, v.38, n.4, p.667-675, 2014 
highest number of private and rare alleles was found in the Pedregulho population, followed by the populations of Itirapina and Brotas.

Observed heterozygosity values were lower than expected in all populations, indicating an excess of homozygotes. All populations deviated from HardyWeinberg Equilibrium (HWE). The deviations may have been caused by selfing and crossing among relatives. Fixation index values were very high in Brotas and Pedregulho (0.198 and 0.189), and higher in Assis and Itirapina (over 0.230).

The analysis of spatial genetic structure (SGS) in populations of $C$. langsdorffii suggested isolation by distance. Sebbenn et al. (2011) also reports the occurrence of SGS in populations of C. langsdorffii studied in São Paulo State. According to Loiselle et al. (1995), the formation of genetic structure could be attributable to limited seed dispersal or vegetative reproduction. The latter possibility should, however, be discarded, as clones were not detected in the populations studied.

The effective population size (number of individuals unrelated and not inbred) was low. The analysis of effective population size changes using the IAM and the TPM identified genetic bottlenecks in all four populations; that is, heterozygote deficits in these populations were observed in a significant number of loci. These findings were not detected by analyses using the SMM. According to Kimura and Crow (1964), the excess or deficit of heterozygosity has only been demonstrated for loci evolving under the IAM. In loci evolving under the SMM (OHTA; KIMURA, 1973), deviations in heterozygosity may not always be detected (CORNUET; LUIKART, 1997). Di Rienzo et al. (1994) suggested that the TPM is more suitable for the analysis of microsatellite loci, as it incorporates the SMM, but takes wide variation in the magnitude of mutations into account, by considering that some mutations involve more than one repeat unit. According to Lee et al. (2002), it is important to identify populations experiencing recent bottlenecks, as they may be at risk of extinction. Luikart et al. (1998) also suggest that when bottlenecks are detected early, their deleterious effects are more likely to be successfully reduced or avoided altogether.

Genetic divergence between populations was high, showing a large genetic isolation between populations. Sebbenn et al. (2011) and Tarazi et al. (2013) found similar results, suggesting that the spatial isolation of populations by habitat fragmentation may reduce genetic diversity and effective population size, restrict pollen and seed gene flow and increase the SGS of new generations.

This result was complemented by the genetic structure analysis, which defined each population as a discrete cluster, although Brotas shared some similarities with Itirapina. However, it is important to note that these were the two geographically closest populations, and experienced probably a high level of gene flow. The genetic distance dendrogram also suggested that these populations were the least genetically distant.

\section{CONCLUSIONS}

The high genetic differentiation observed among populations is consistent with the hypothesis of genetic and geographic isolation. This isolation coupled with anthropic pressure that causes fragmentation of remaining Cerrado could be causing the decrease of genetic diversity. It is important to perform this study in different populations of Copaifera langsdorffii Desf. to check if the results are repeated. Likewise, it is essential to adopt conservation strategies that raise the gene flow between fragments.

\section{REFERENCES}

ANTIQUEIRA, L. M. O. R. Application of microsatellite molecular markers in studies of genetic diversity and conservation of plant species of cerrado Journal of Plant Sciences, v.1, n.1, p.1-5, 2013.

BRASIL. Ministério do Meio Ambiente. Programa Nacional de Conservação e Uso Sustentável do Bioma Cerrado Programa Cerrado Sustentável. Brasília: 2006. 56p.

CARVALHO, A. C. M. et al. Diversidade genética, endogamia e fluxo gênico em pequena população fragmentada de Copaifera langsdorffii. Revista Brasileira de Botânica, v.33, n.4, p.599-606, 2010.

\author{
CARVALHO, P. E. R. Espécies arbóreas \\ brasileiras: recomendações \\ silviculturais, potencialidades e uso de \\ madeira. Colombo: EMBRAPA/CNPF, 2003. 639p.
}


CIAMPI, A. Y.; BRONDANI, R. P. V.; GRATTAPAGLIA, D. Desenvolvimento de marcadores microssatélites para Copaifera langsdorffii Desf. (copaíba) LeguminosaeCaesalpinoideae e otimização de sistemas fluorescentes de genotipagem multiloco. Boletim de Pesquisa da Embrapa Recursos Genéticos e Biotecnologia, v.16, p.1-40, 2000.

COCKERHAM, C. C. Variance of gene frequency. Evolution, v.23, n.1, p.72-74, 1969.

CORNUET, J. M.; LUIKART, G. Description and power analysys of two tests for detecting recent population bottlenecks for allele frequency data. Genetics, v.144, n.4, p.2001-2014, 1997.

CRESTE, S.; TULMANN NETO, A.; FIGUEIRA, A. Detection of single sequence repeat polymorphisms in denaturing polyacrylamide sequencing gels by silver staining. Plant Molecular Biology Reporter, v.19, p.299-306, 2001.

CROW, J. F.; AOKI, K. Group selection for polygenic behavioral trait: estimating the degree of population subdivision. Proceedings of the National Academy of Science of the United States of America, v.81, p.6073-6077, 1984.

DI RIENZO, A. et al. Mutational processes of simple sequence repeat loci in human populations. Proceedings of the National Academy of Science of the United States of America, v.91, n.8, p.3166-3170, 1994.

DOYLE, J. J.; DOYLE, J. L. Isolation of DNA from fresh tissue. Focus, v.12, n.1, p.13-15, 1990.

EVANNO, G.; REGNAUT, S.; GOUDET, J. Detecting the number of clusters of individuals using the software Structure: a simulation study. Molecular Ecology, v.14, n.8, p.2611-2620, 2005.

FERREIRA, M. E.; GRATTAPAGLIA, D. Introdução ao uso de marcadores moleculares em análise genética. Brasília: Embrapa Cenargen, 1998. 220p.

GOUDET, J. FSTAT: a program to estimate and test gene diversities and fixation indices Lausanne: Universidade de Lausanne, do Departamento de Ecologia e Evolução, 2002
HARDY, O.; VEKEMANS, X. SPAGeDI: a versatile computer program to analyse spatial genetic structure at the individual or population levels. Molecular Ecology Notes, v.2, p.618-620, 2002.

HEDRICK, P. W. A standardized genetic differentiation measure. Evolution, v.59, n.8, p.1633-1638, 2005.

KALINOWSKI, S.T.; TAPER, M.L.; MARSHALL, T.C. Revising how the computer program CERVUS accommodates genotyping error increases success in paternity assignment. Molecular Ecology, v.16, n.5, p.1099-106, 2007.

KIMURA, M.; CROW, J. F. The number of alleles that can be maintained in a finite population. Genetics, v.49, n.4, p.725-738, 1964.

KRONKA, F. J. N. et al. Inventário florestal da vegetação natural do Estado de São Paulo. São Paulo: Imprensa Oficial, 2005. 200p.

LEE, S. L. et al. Population genetics of Intsia paelmbanica (Leguminosae) and genetic conservation of Virgin Jungle Reserves in Peninsular Malaysia. American Journal of Botany, v.89, n.3, p.447-459, 2002.

LOISELLE, B. A. et al. Spatial genetic structure of a tropical understory shrub, Psychotria officinalis (Rubiaceae). American Journal of Botany, v.82, n.11, p.1420-1425, 1995.

LUIKART, G. et al. Distortion of allele frequency distributions provides a test for recent population bottlenecks. Journal of Heredity, v.89, n.3, p.238-247, 1998.

LUIKART, G.; CORNUET, J. M. Empirical evaluation of a test for identifying recently bottlenecked populations from allele frequency data. Conservation Biology, v.12, n.1, p.228-237, 1998.

LYNCH, M. A quantitative-genetic perspective on conservation issues. In: AVISE, J. C.; HAMRICK, J. L. (Ed.). Conservation genetics: case studies from nature. New York: Chapman \& Hall, 1996. p.471-501.

MACHADO, R. B. et al. Estimativas de perda da área do Cerrado brasileiro. Relatório técnico não publicado. Brasília: Conservação Internacional, 2004. 25p. 
MILLER, M. P. TFPGA - Tools for populations genetics analysis. Disponível em < http://www.marksgeneticsoftware.net/>. Acesso em: 21 de maio de 2013.

MITTERMEIER, R. A. et al. Hotspots revisited: earth's biologically richest and most endangered terrestrial ecoregions. Boston: Cemex, 2005. 431p.

NEI, M. Molecular evolutionary genetics. New York: Columbia University Press, 1987.

OHTA, T.; KIMURA, M. A model of mutation appropriate to estimate the number of electrophoretically detectable alleles in a finite population. Genetic Research, v.33, p.201204, 1973.

OLIVEIRA, A. F.; CARVALHO, D.; ROSADO, S. C. $\mathrm{S}$. Taxa de cruzamento e sistema reprodutivo de uma população natural de Copaiba langsdorffii Desf. na região de Lavras (MG) por meio de isoenzimas. Revista Brasileira de Botânica, v.25, n.3, p.331-338, 2002.

PIRY, S.; LUIKART, G.; CORNUET, J. M. Bottleneck: a computer program for detecting recent reductions in the effective size using allele frequency data. Heredity, v.90, n.4, p.502-503, 1999.

PRITCHARD, J.; STHEPENS, M.; DONNELLY, P. Inference of population structure using multilocos genotype data. Genetics, v.155, n.2, p.945-959, 2000.
QUEIROZ, L. P.; SILVA, R. C. V. M. D. Copaifera in Lista de Espécies da Flora do Brasil., Rio de Janeiro, 2013. Disponível em: < http://floradobrasil.jbrj.gov.br/jabot/floradobrasil/

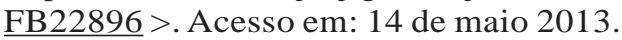

RIBEIRO, J. F.; WALTER, B. M. T. Fitofisionomias do bioma cerrado. In: SANO, S.; ALMEIDA, S. P. (Ed.). Cerrado: ambiente e flora. Planaltina: Embrapa Cerrados, 1998. p.87-166.

ROLIM, G. S. et al. Classificação climática de Köppen e de Thornthwaite e sua aplicabilidade na determinação de zonas agroclimáticas para o estado de São Paulo. Bragantia, v.66, n.4, p.711-720, 2007.

SEBBENN, A. M. et al. Low levels of realized seed and pollen gene flow and strong spatial genetic structure in a small, isolated and fragmented population of the tropical tree Copaifera langsdorffii Desf. Heredity, v.106, n.1, p.134-45, 2011.

TARAZI, R. et al. Long-distance dispersal in a fire- and livestock-protected savanna. Ecology and Evolution, v.3, n.4, p.1003-15, 2013.

WEIR, B. S. Genetic data analysis II: methods for discrete population genetic data. Sunderland: Sinaver Associates, 1996. 445p.

WHITTAKER, R. J.; FERNÁNDEZ-PALACIOS, J. M. Island biogeography: ecology, evolution, and conservation. 2.ed. Oxford/New York: Oxford University Press, 2007. 401p. 
